\title{
OIL MARKET AMID LOW PRICES
}

\author{
Yu.Bobylev
}

Global oil marker is characterized by low oil prices resulting from an excessive supply over demand $d^{1}$ Under the effect of low prices oil production on cost-intensive oilfields began falling, drastically decreased investments in the development of unconventional petroleum deposits including shale oil in the US. Over recent months, it is observed that the oil production is shrinking in the United States. Contraction of cost-intensive crude production creates preconditions for a reduction of excessive oil supply and consequently oil price hike. However, risks remain emanating from the OPEC member states who strive to increase their market share. Presently, reduction of oil production on the cost-intensive oilfields is counterbalanced by the production growth in the OPEC. Russian oil sector demonstrates positive dynamics and rather high investment activity which allows to reckon on preserving gains achieved in the oil production in the near-term.

Oil glut on the global crude market resulted in stable low oil prices. At the same time, OPEC refused to reduce oil production quotas and passed to protecting its oil market share. For January-September 2015, price of Urals on the global market averaged $54.3 \mathrm{USD} / \mathrm{bbl}$. down $44.4 \%$ of the average level last year (Table 1). Thus, low oil prices became new normal of the crude market.

Table 1

GLOBAL OIL PRICES IN 2012-2015 USD/BBL.

\begin{tabular}{|c|c|c|c|c|c|c|}
\hline & \multirow{2}{*}{2012} & \multirow{2}{*}{2013} & \multirow{2}{*}{2014} & \multicolumn{3}{|c|}{2015} \\
\hline & & & & Q1 & Q2 & Q3 \\
\hline $\begin{array}{l}\text { Price of Brent, } \\
\text { Great Britain }\end{array}$ & 112.0 & 108.8 & 98.9 & 54.0 & 61.9 & 50.0 \\
\hline $\begin{array}{l}\text { Price of Urals, } \\
\text { Russia }\end{array}$ & 110.3 & 107.7 & 97.7 & 52.8 & 61.0 & 49.1 \\
\hline
\end{tabular}

Sources: IMF, OECD/IEA.

Main factors of significant growth of the global oil supply were rapid increase of shale oil production in the US thanks to the application of innovative technologies and financed by high oil prices. Only for the last three years (2012-2014), oil production in the US went up by $55 \%$, at the same time in 2014 , annual increment constituted $17 \%$. However, recent data demonstrates that due to low oil prices the outlook has drastically changed contraction of oil production on the costintensive oil fields and sharp decrease of investments. Peak oil production in the US was achieved in April $2015-9.61 \mathrm{mn}$ bbl. per day. Thereafter, oil production fell to 9.13 million barrels per day in September or by $5 \%$ compared to April (Fig. 2).

Sub-economic development of many oil deposits amid low crude prices determined transfer of dates and refusal to implement many investment projects.

1 This article was originally published in Monitoring of Russia's Economic Outlook. Trends and Challenges of Socio-economic Development. 2015. No. 14. October.

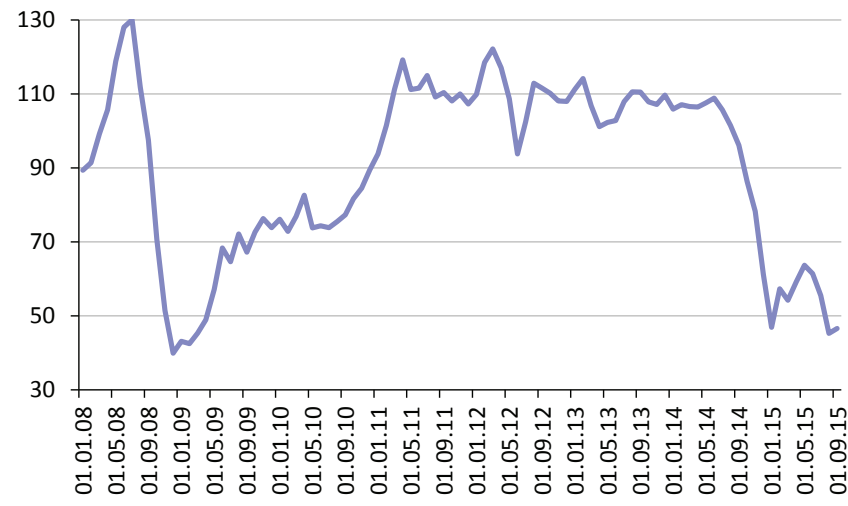

Sources: OECD/IEA.

Fig. 1. Price of Urals in 2008-2015 USD/barrel

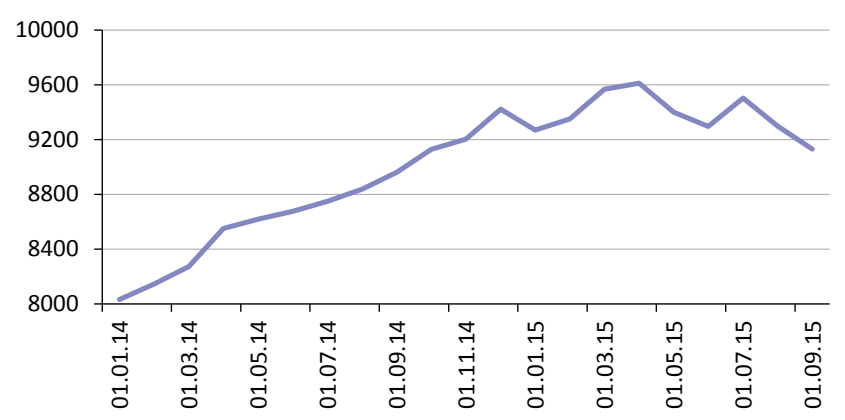

Source: US EIA.

Fig. 2. The US crude oil production in 2014-2015 thousand barrels per day

First of all, it referred to the investment in the development of highly cost-intensive unconventional petroleum deposits - shale oil in the US, bituminous sands in Canada, and deep sea deposits in various regions. According to Barclays Research estimates, contraction of investment in oil production in North America will come to $35 \%$ in 2015.

Rig count represents an indicator of the investment activity in the sector. In the US this indicator reached its maximum - 1,596 rigs - in October 20145. 
Thereafter, there was a steady decline (Fig. 3). In September 2015, rig count was barely 650 units, i.e. fell by $59 \%$ compared to October last year. The same picture is observed in Canada where the rig count over last 12 months reduced from 232 to 74 or by $68 \%$.

Because of the reduction of cost-intensive production in the coming year, one can expect a fall of excessive oil supply which will create preconditions for certain hike in the oil prices. At the same time, from the supply point of view there remain certain risks emanating from some OPEC member states which (including Saudi Arabia) tend to increase their market share. As a result, decrease of oil production in the cost-intensive regions is presently counterbalanced by an increase of production by OPEC. In Q3 2015, in the context of the oil production decline in the US by 240 thousand barrels per day, OPEC oil production increased by 290 thousand barrels per day including in Saudi Arabia - by 180 thousand barrels per day. Iraq has substantially increased oil production (Table 2). Iran announced its plans to significantly increase its oil production and export in the event of lifting sanctions.

Table 2

\section{OIL PRODUCTION IN THE US AND OPEC IN 2014-2015} MN BBL. PER DAY

\begin{tabular}{l|c|c|c|c|c|c|c|c|} 
& \multicolumn{5}{|c|}{2014} & \multicolumn{3}{|c}{2015} \\
\hline & Q1 & Q2 & Q3 & Q4 & Q1 & Q2 & Q3 \\
\hline $\begin{array}{l}\text { USA } \\
\text { OPEC, } \\
\text { total }\end{array}$ & 8.14 & 8.61 & 8.84 & 9.25 & 9.39 & 9.41 & 9.17 \\
\hline $\begin{array}{l}\text { Saudi } \\
\text { Arabia }\end{array}$ & 9.80 & 9.65 & 9.70 & 9.63 & 9.73 & 10.07 & 10.25 \\
\hline $\begin{array}{l}\text { Iraq } \\
\text { Ina }\end{array}$ & 3.26 & 3.29 & 3.28 & 3.53 & 3.57 & 4.03 & 4.21 \\
\hline
\end{tabular}

Source: US EIA.

In Russia, despite the fall of oil prices and introduction of financial and technological sanctions, positive dynamics in oil production remain. In January-September 2015 against the corresponding period of the previous year, oil production increased by $1.4 \%$ (Table 3, Fig. 4). Investments, ruble depreciation as well as reduction of the tax burden which followed the fall off the global oil prices have positively affected oil production. That said, there was a notable change in the number of trends in the downstream segment which, in our opinion, should be viewed as initial positive effects of the tax maneuver. ${ }^{1}$ Among them should be noted, firstly, reduction of fuel oil production which happened for the first time over last year, secondly, growth of crude oil exports which happened for the first time over recent years (which is more profitable for the state budget compared to the export of fuel oil), thirdly, reduction of the oil refining volume resulting from the first two factors.

1 See: Yu. Bobylev. Tax Maneuver in the Oil Sector. Russian Economic Developments. 2015, No. 8, pp. 45-49.

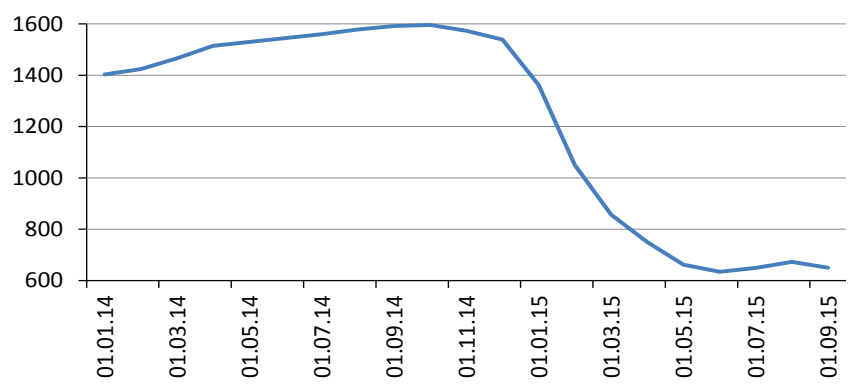

Source: Baker Hughes.

Fig.3. Rig count in the US in 2014-2015

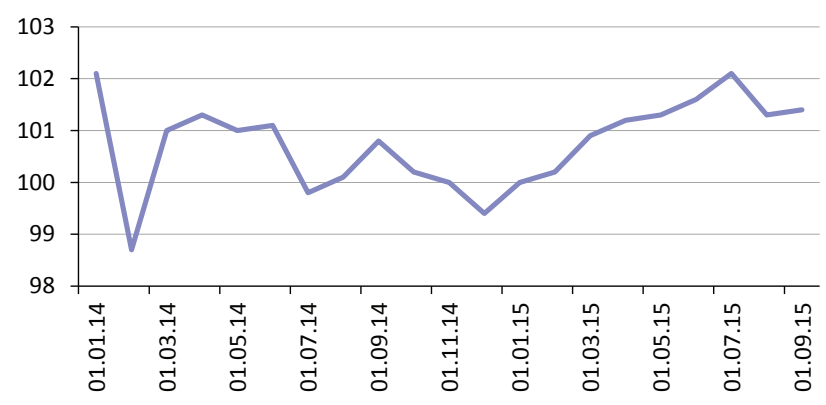

Source: Rosstat.

Fig. 4. Oil production in Russia in 2014-2015, \% to corresponding period of previous year

Table 3

PRODUCTION AND EXPORT OF OIL AND PETROLEUM PRODUCTS IN 2012-2015, \% TO CORRESPONDING PERIOD OF PREVIOUS YEAR

\begin{tabular}{|l|c|c|c|c|}
\hline & 2012 & 2013 & 2014 & $\begin{array}{c}2015 \\
\text { January- } \\
\text { September }\end{array}$ \\
\hline $\begin{array}{l}\text { Oil production, includ- } \\
\text { ing gas condensate }\end{array}$ & 101.3 & 100.9 & 100.7 & 101.4 \\
\hline $\begin{array}{l}\text { Export of crude } \\
\text { Primary crude }\end{array}$ & 98.2 & 98.6 & 94.4 & 107.0 \\
\hline $\begin{array}{l}\text { oil processing } \\
\text { Production of gasoline }\end{array}$ & 104.9 & 102.7 & 104.9 & 98.1 \\
\hline Production of diesel fuel & 98.7 & 101.3 & 98.8 & 103.2 \\
\hline Production of fuel oil & 101.6 & 103.3 & 107.4 & 99.3 \\
\hline
\end{tabular}

Sources: Rosstat, Ministry of Energy of Russia.

At the same time, one should note the retention of rather high level of the investment activity in Russia's upstream segment. In H1 2015,rig count up 7.5\% compared to the corresponding period of the previous year, the volume of production drilling up $9.8 \%$ (Table 4).

Table 4

INDICATORS OF THE INVESTMENT ACTIVITY IN THE UPSTREAM SEGMENT IN 2014-2015

\begin{tabular}{|l|c|c|c|}
\hline & H1 2014 & H1 2015 & $\begin{array}{c}\text { H1 2015 in \% to } \\
\text { H1 2014 }\end{array}$ \\
\hline Investment, Rb bln. & 422.8 & 473.7 & 112.0 \\
\hline New rigs, units & 2,750 & 2,955 & 107.5 \\
\hline
\end{tabular}


Table 4, cont'd

\begin{tabular}{|l|c|c|c|}
\hline & H1 2014 & H1 2015 & $\begin{array}{c}\text { H1 } 2015 \text { in \% to } \\
\text { H1 } 2014\end{array}$ \\
\hline $\begin{array}{l}\text { Exploration drill- } \\
\text { ing, thousand } M\end{array}$ & 405.0 & 449.8 & 111.1 \\
\hline $\begin{array}{l}\text { Production drill- } \\
\text { ing, thousand } M\end{array}$ & $9,354.1$ & $10,271.5$ & 109.8 \\
\hline
\end{tabular}

Source: CDS FEC.
One should expect that by 2015 year-end oil production in Russia would exceed $530 \mathrm{mn} t$ and it will be the highest level since 1990. Current outlook in Russia's oil sector allows to reckon on the retention of the production volumes in the near-term. 